\title{
THE PERCEPTIONS OF AGILE METHODOLOGY IN SOUTH AFRICA
}

\author{
Thierry Mbah Mbelli ${ }^{1}$ and Jainesh Jaintylal Hira $^{2}$ \\ ${ }^{1}$ Deloitte Digital, Woodmead, Johannesburg, South Africa \\ tmbelli@deloitte.co.za \\ ${ }^{2}$ First National Bank, Sandton, Johannesburg, South Africa \\ jainesh.hira@fnb.co.za
}

\begin{abstract}
Agile methodology was introduced in the mid 90's while the agile manifesto was adopted in 2001. The rationale behind the introduction of the agile methodology was to uncover better ways of developing software that will meet the user's expectation in an iterative controlled manner. With technological explosion and rift competition for market share, user experience and satisfaction can only be achieved through proper communication between stakeholders and innovative ways of doing things. Doing things differently is what the agile methodology brought. Despite the existence of this methodology for over 20 years now, South African software industry is only starting to realize its existence with a lot of companies jumping into the bandwagon. This paper presents the results of an empirical research of how the South African software industry perceive the methodology.
\end{abstract}

\section{KEYWORDS}

Agile methodology, Software crisis, Agile manifesto, Scrum, Extreme programming

\section{INTRODUCTION}

Every business and every economy depends on technology to survive in a very competitive space nowadays and this has created what some people called 'technology war' or 'software war'. Agile methodology helps to cushion this war and prepares the software industry to manoeuvre the war by introducing methods that place more emphasis on people and their creativity, communication and the ability to produce quality software within a relatively short space of time and within budget. Agile methodology is a very popular approach to developing software but very little is understood about its penetration, successes, benefits, failures and problems [5]. Scrum and Extreme Programming are the most popular agile methodologies that are currently used in South Africa

This paper presents an understanding of how the agile methodology is being perceived in South Africa, what is the general understanding of the methodology by the industry practitioners. Empirical research method was used to gain this understanding. Through this understanding, an insight of the interaction of the development practices and the perceptions of the agile methodology was established.

Jan Zizka et al. (Eds) : CCSIT, SIPP, AISC, CMCA, SEAS, CSITEC, DaKM, PDCTA, NeCoM - 2016

pp. 219-227, 2016. @ CS \& IT-CSCP 2016

DOI : $10.5121 / \mathrm{csit} .2016 .60119$ 
A web-based survey targeting software development professionals involved in the development, testing and management was conducted. Invitations were sent out by email to 905 selected professionals with instructions of how to complete the anonymous web-based questionnaires. The questions were structured to understand the respondents' understanding of the agile methodology, which agile method was adopted in their team, the successes and failures of agile methodology, their experience in software development, their role in the team, their qualification and their perception of why the methodology works or not work in their development teams. The response rate was $20 \%$ with 181 responses received.

From the responses, a perception of the agile methodology was established and scrum was identified as the most common of the agile methods adopted. $58 \%$ of the respondents have at least two years' experience in the development of software. $40.9 \%$ have at least an undergraduate degree. Less than $8.8 \%$ have a postgraduate degree. About $41.4 \%$ indicated that agile methodology doesn't work in their teams, while $44.2 \%$ indicated that agile methodology is working in their teams, thus a slight approval of the methodology.

The remainder of this paper is structured as follow: Section 2 discusses what work has been done in different parts of the world on this topic. Section 3 discusses the methodology that was used to come out with the findings. Section 4 presents the findings and lastly, section 5 concludes with a review of the findings and the implications for future research in the South African context.

\section{LITERATURE REVIEW}

Agile methodology represents a major shift from the traditional approach of developing software to a more engineering-like approach. Prior to the emergence of the agile methodology, software development had issues and problems - 'software crisis'. The software crisis was due to the complexity of problems that the engineering methods available could not tackle [3]. The agile methodology brought some shift in the approach to solve complex problems and the adoption of this methodology depends on the suitability and skills of the team members, the organization and the type of project.

The agile manifesto prophesizes four main value [2]:

- More interaction between team members and less emphasis on processes and tools

- More emphasis on producing a working software and less emphasis on detailed documentation

- More customer collaboration in the development process and less contract negotiation

- Ability to rapidly respond to change than following a detailed plan

There is a general perception that agile methodology is widely used in South Africa but there is little or no evidence to validate this perception. This paper aims at addressing this perception and to some level assesses the current state of the practice of the methodology in South Africa.

This research is closely related to the work of Begel and Nagappan [1]. They investigated the usage and perception of agile software development in Europe, Asia and North America 
specifically at Microsoft. Africa in general and South Africa in particular was not included in that investigation. They conducted a web based survey of Microsoft employees in the development, testing and management teams. Their research was based at understanding the respondents' demographics, usage and penetration of agile development practices and the general perception of the agile methods. They found out that overwhelming majority of the respondents favoured the adoption of the agile methods.

Nithila et al.'s [4] also conducted a similar study in Sri Lanka and they found out that majority of the respondents favoured the adoption of the agile methodology. In their study they found out that only $31 \%$ of the respondents disapproved the agile methodology.

\section{METHODOLOGY}

The primary objective of this investigation was to establish the perception of the agile methodology in South Africa. The research was done through a web-based survey questionnaires and the participants were invited via email. A random sample of the respondents was selected for an informal interviews.

A total of 905 invitations were sent and 181 responses were received giving the response rate of $20 \%$. The response rate for the different groups were as followed; software developers $21.0 \%$, managers $11.6 \%$ software engineers $14.4 \%$, testers $14.9 \%$, architects $12.7 \%$, analyst $17.7 \%$, infrastructure and software support $7.7 \%$.

The study was conducted over a period of four weeks from April 8, 2013 to May 6, 2013 and the respondents were asked 30 questions. The questions were divided into two sections; personal section that dealt with qualification, role in the team and development experience, agile development section that dealt with perception, successes and failures of the agile methodology.

In the personal section, the questions were designed to understand who the respondents are and their qualification, role in the team and professional experience. In the agile development section, the questions were designed to better understand the respondents' perceptions of the agile methodology. The respondents were asked if they like the agile methodology, whether they understand the concept behind the agile methodology, whether the methodology is working well or poorly in their teams, what are the successes and failures of the methodology. In this section, the respondents had the freedom to express their personal opinion.

\section{RESULTS AND DISCUSSION}

From the results, it was established that the number of respondents who have or had an excellent or good and the number of respondents who have or had a poor or very poor experience with the agile methodology were equal. The trend also indicated that respondents with degree tend to favour the adoption of the agile methodology while respondents without degree tend to disfavour the adoption of the agile methodology. 
Table 1. Respondents per group

\begin{tabular}{|l|l|l|}
\hline Role & No of respondents & Percentage \\
\hline Software developers & 38 & 21.0 \\
\hline Managers & 21 & 11.6 \\
\hline Software engineers & 26 & 14.4 \\
\hline Testers & 27 & 14.9 \\
\hline Architects & 23 & 12.7 \\
\hline Analysts & 32 & 17.7 \\
\hline Infrastructure \& support & 14 & 7.7 \\
\hline
\end{tabular}
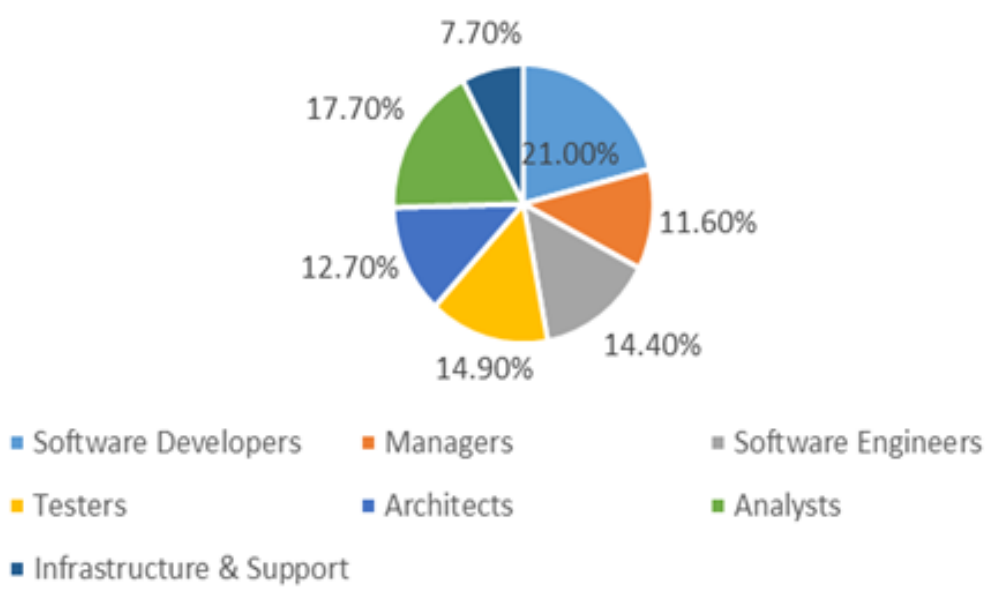

- Infrastructure \& Support

Figure 1. Respondents per group

Table 2. Qualification per respondents

\begin{tabular}{|l|l|l|l|}
\hline Role & No degree & $\begin{array}{l}\text { Undergraduate } \\
\text { degree }\end{array}$ & $\begin{array}{l}\text { Postgraduate } \\
\text { degree }\end{array}$ \\
\hline $\begin{array}{l}\text { Software } \\
\text { developers }\end{array}$ & 22 & 12 & 4 \\
\hline Managers & 10 & 10 & 1 \\
\hline $\begin{array}{l}\text { Software } \\
\text { engineers }\end{array}$ & 6 & 12 & 8 \\
\hline Testers & 18 & 9 & 0 \\
\hline Architects & 11 & 10 & 2 \\
\hline Analysts & 11 & 20 & 1 \\
\hline $\begin{array}{l}\text { Infrastructure } \\
\& \text { support }\end{array}$ & 13 & 1 & 0 \\
\hline
\end{tabular}

Table 3. Work experience per respondents

\begin{tabular}{|l|l|l|}
\hline Duration & No of respondents & Percentage \\
\hline $0-6$ months & 26 & 14.4 \\
\hline $\begin{array}{l}6 \text { months }-2 \\
\text { years }\end{array}$ & 50 & 27.6 \\
\hline 2 years -5 years & 57 & 31.5 \\
\hline 5 years + & 48 & 26.5 \\
\hline
\end{tabular}


Table 4. Usage of agile methodology

\begin{tabular}{|l|l|l|}
\hline Usage & No of respondents & Percentage \\
\hline Currently using & 108 & 59.7 \\
\hline Once used & 43 & 23.8 \\
\hline Never used & 30 & 16.5 \\
\hline
\end{tabular}

Table 5. Software developers' experience with agile

\begin{tabular}{|l|l|l|}
\hline Experience & No of respondents & Percentage \\
\hline Excellent & 2 & 5.3 \\
\hline Good & 14 & 36.8 \\
\hline Poor & 10 & 26.3 \\
\hline Very poor & 4 & 10.5 \\
\hline Don't know & 8 & 21.1 \\
\hline
\end{tabular}

Table 6. Managers' experience with agile

\begin{tabular}{|l|l|l|}
\hline Experience & No of respondents & Percentage \\
\hline Excellent & 0 & 0 \\
\hline Good & 8 & 38.1 \\
\hline Poor & 8 & 38.1 \\
\hline Very poor & 5 & 23.8 \\
\hline Don't know & 0 & 0 \\
\hline
\end{tabular}

Table 7. Software engineers' experience with agile

\begin{tabular}{|l|l|l|}
\hline Experience & No of respondents & Percentage \\
\hline Excellent & 8 & 30.8 \\
\hline Good & 10 & 38.5 \\
\hline Poor & 6 & 23.1 \\
\hline Very poor & 2 & 7.6 \\
\hline Don't know & 0 & 0 \\
\hline
\end{tabular}

Table 8. Testers' experience with agile

\begin{tabular}{|l|l|l|}
\hline Experience & No of respondents & Percentage \\
\hline Excellent & 0 & 0 \\
\hline Good & 9 & 33.3 \\
\hline Poor & 9 & 33.3 \\
\hline Very poor & 6 & 22.3 \\
\hline Don't know & 3 & 11.1 \\
\hline
\end{tabular}

Table 9. Architects' experience with agile

\begin{tabular}{|l|l|l|}
\hline Experience & No of respondents & Percentage \\
\hline Excellent & 1 & 4.4 \\
\hline Good & 8 & 34.8 \\
\hline Poor & 8 & 34.8 \\
\hline Very poor & 1 & 4.4 \\
\hline Don't know & 5 & 21.6 \\
\hline
\end{tabular}


Table 10. Analysts' experience with agile

\begin{tabular}{|l|l|l|}
\hline Experience & No of respondents & Percentage \\
\hline Excellent & 4 & 12.5 \\
\hline Good & 16 & 50.0 \\
\hline Poor & 6 & 18.8 \\
\hline Very poor & 4 & 12.5 \\
\hline Don't know & 2 & 6.2 \\
\hline
\end{tabular}

Table 11. Infrastructure \& support experience with agile

\begin{tabular}{|l|l|l|}
\hline Experience & No of respondents & Percentage \\
\hline Excellent & 0 & 0 \\
\hline Good & 0 & 0 \\
\hline Poor & 3 & 21.4 \\
\hline Very poor & 3 & 21.4 \\
\hline Don't know & 8 & 57.2 \\
\hline
\end{tabular}

Table 12. General experience with agile methodology

\begin{tabular}{|l|l|l|}
\hline Experience & No of respondents & Percentage \\
\hline Excellent & 15 & 8.3 \\
\hline Good & 65 & 35.9 \\
\hline Poor & 50 & 27.6 \\
\hline Very poor & 25 & 13.8 \\
\hline Don't know & 26 & 14.4 \\
\hline
\end{tabular}

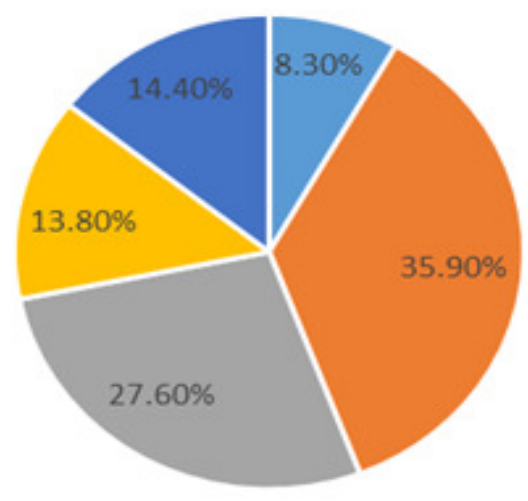

- Excellent = Good = Poor = Very Poor " Don't know

Figure 2: General experience with agile methodology 
Table 13. Software developers' interest in agile

\begin{tabular}{|l|l|l|}
\hline Interested & No of respondents & Percentage \\
\hline Very interested & 3 & 7.9 \\
\hline Interested & 9 & 23.7 \\
\hline Not interested & 18 & 47.4 \\
\hline Don't know & 8 & 21.0 \\
\hline
\end{tabular}

Table 14. Managers' interest in agile

\begin{tabular}{|l|l|l|}
\hline Interested & No of respondents & Percentage \\
\hline Very interested & 2 & 9.5 \\
\hline Interested & 8 & 38.1 \\
\hline Not interested & 6 & 28.6 \\
\hline Don't know & 5 & 23.8 \\
\hline
\end{tabular}

Table 15. Software engineers' interest in agile

\begin{tabular}{|l|l|l|}
\hline Interested & No of respondents & Percentage \\
\hline Very interested & 7 & 26.9 \\
\hline Interested & 16 & 61.5 \\
\hline Not interested & 2 & 7.8 \\
\hline Don't know & 1 & 3.8 \\
\hline
\end{tabular}

Table 16. Testers' interest in agile

\begin{tabular}{|l|l|l|}
\hline Interested & No of respondents & Percentage \\
\hline Very interested & 0 & 0 \\
\hline Interested & 5 & 18.5 \\
\hline Not interested & 14 & 51.9 \\
\hline Don't know & 8 & 29.6 \\
\hline
\end{tabular}

Table 17. Architects' interest in agile

\begin{tabular}{|l|l|l|}
\hline Interested & No of respondents & Percentage \\
\hline Very interested & 2 & 8.7 \\
\hline Interested & 5 & 21.7 \\
\hline Not interested & 13 & 56.6 \\
\hline Don't know & 3 & 13.0 \\
\hline
\end{tabular}

Table 18. Analysts' interest in agile

\begin{tabular}{|l|l|l|}
\hline Interested & No of respondents & Percentage \\
\hline Very interested & 5 & 15.6 \\
\hline Interested & 13 & 40.6 \\
\hline Not interested & 11 & 34.4 \\
\hline Don't know & 3 & 9.4 \\
\hline
\end{tabular}


Table 19: Infrastructure \& support's interest in agile

\begin{tabular}{|l|l|l|}
\hline Interested & No of respondents & Percentage \\
\hline Very interested & 0 & 0 \\
\hline Interested & 0 & 0 \\
\hline Not interested & 10 & 71.4 \\
\hline Don't know & 4 & 28.6 \\
\hline
\end{tabular}

Table 20: General interest in agile methodology

\begin{tabular}{|l|l|l|}
\hline Interested & No of respondents & Percentage \\
\hline Very interested & 19 & 10.5 \\
\hline Interested & 56 & 30.9 \\
\hline Not interested & 74 & 40.9 \\
\hline Don't know & 32 & 17.7 \\
\hline
\end{tabular}

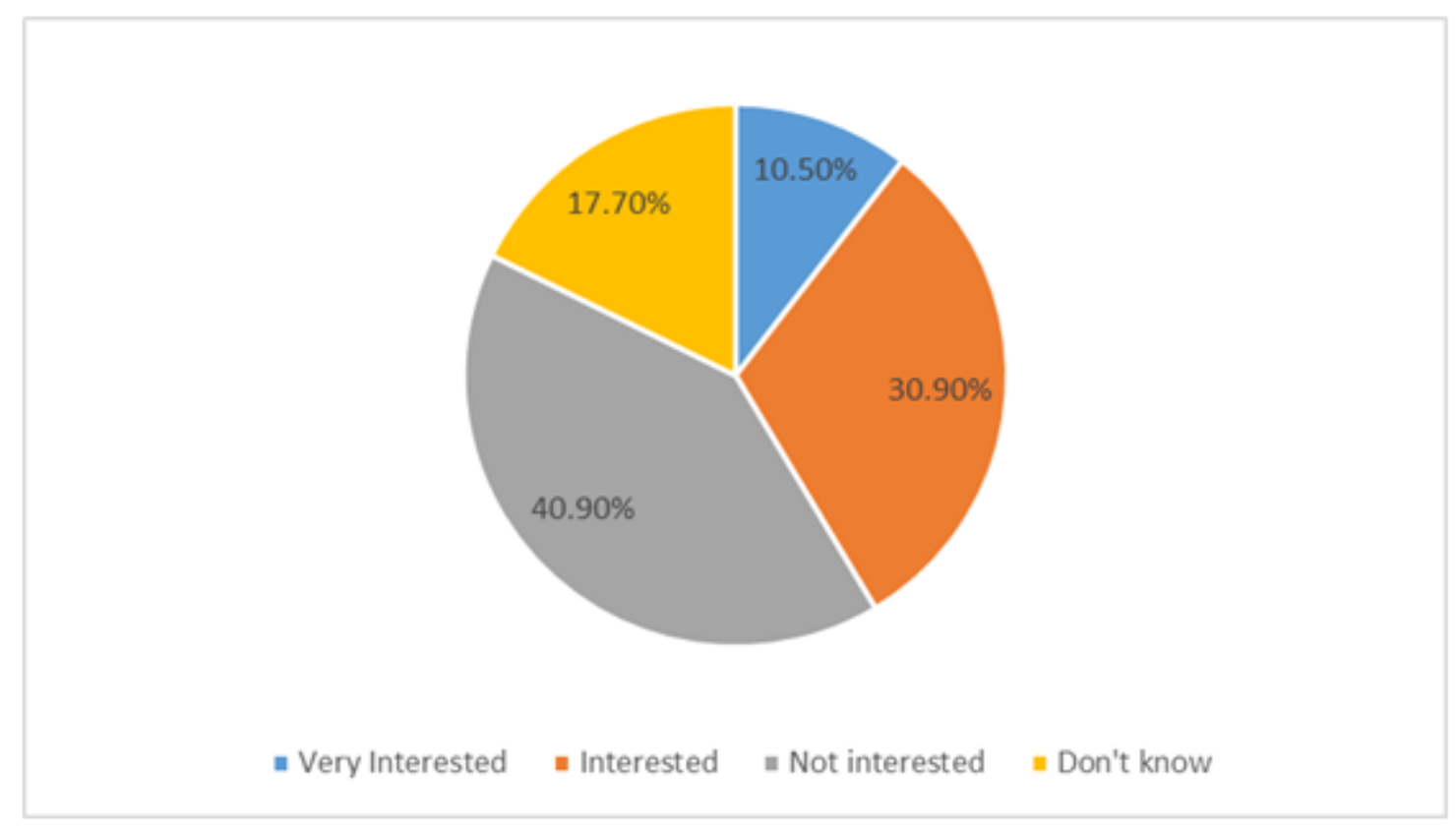

Figure 3: General interest in agile methodology

\section{CONCLUSION AND FUTURE WORK}

The main objective of this research was to investigate the perception of the agile methodology in the South African software development industry. The main findings were that $8.3 \%$ of the respondents have or had an excellent experience with the adoption of the agile methodology in their teams and $35.9 \%$ have or had a good experience while $27.6 \%$ have or had a poor experience with only $13.8 \%$ having a very poor experience with the adoption of the agile methodology.

Looking at the interest in adopting the methodology in the teams, $10.5 \%$ were very interested, $30.9 \%$ were interested while $40.9 \%$ were not interested and 17.7 were undecided. 
Analysis of the results showed that software engineers are more in favour of adopting the agile methodology with $61.5 \%$ while $71.4 \%$ of infrastructure and support respondents do not support the adoption of the methodology in their teams.

The results gives a clear indication of how the agile adoption is perceived in South Africa. The follow up to this work could be an in-depth investigation of the level of adoption and penetration of the agile methodology in the South African software development industry, what are the failures and successes, what are the limitations and benefits.

In general, there was an impression among the respondents especially the developers that, there is not a single way to practice agile methodology and if a particular methodology was to be followed in the development of software, this methodology has to be followed to the latter, if not, there will be unforeseen consequences. This is somehow absurd as any agile methodology is supposed to be adaptive to the project needs and changes [6].

\section{ACKNOWLEDGEMENTS}

We would like to thank all those respondents who took time to respond to the questions and their feedback that made this paper possible. We would also like to give special thanks to Prof. Barry Dwolatzky from the University of the Witwatersrand for his contribution in guiding us into how to conduct research when we were master students at the university.

\section{REFERENCES}

[1] A. Begel, N. Nagappan. Usage and Perceptions of Agile Software Development in an Industrial Context: An Exploratory Study, ESEM '07 Proceedings of the First International Symposium on Emperical Software Engineering and Measurements, 2007.

[2] Agile Manifesto. Twelve Principles of Agile Software, http://agilemanifesto.org. Last accessed on April 4, 2013.

[3] Alex Colburn Jonathan Hsieh Matthew Kehrt Aaron Kimball. There is no software engineering crisis. January 16, 2008.

[4] S.Nithila, K. Priyadharshani, Y. S. G. Attanayake, T. Arani and C.D. Manawadu. Emergence of Agile Methodologies: "Perceptions from Software Practitioners in Sri Lanka". International Journal of Scientific and Research Publications, Volume 3, Issue 11, November 2013.

[5] A. Asnawi, A. Gravell, G. Wills. An Empirical Study: Understanding Factors and Barriers for implementing Agile Methods in Malaysia, IDoESE'10, Sept. 2010.

[6] C. Tsun and C. Dac-Buu, "A Survey Study of Critical Success Factors in Agile Software Projects", Journal of Systems and Software, vol. 81, pp. 961-971, June 2008.

[7] A. Asnawi, A. Gravell, G. Wills. An Empirical Study: Understanding Factors and Barriers for implementing Agile Methods in Malaysia, IDoESE'10, Sept. 2010. 